\title{
Faunal diversity of Ajmer Aravalis with special reference to Reptiles
}

\author{
Dr Rashmi Sharma \\ Dept. Of Zoology Spc Gca Ajmer Rajasthan India
}

\begin{abstract}
Reptiles are cold blooded vertebrates which breath by lungs throughout their existence and have the body covered by scales. The skull articulates with the vertebral column by a single median occipital condyle. This is the way reptiles can be distinguished by other vertebrates. Ajmer is located in the center of Rajasthan (INDIA) between 25038 " and 26058 " north Latitude and 73054 " and 75022 " east longitude covering a geographical area of about $8481 \mathrm{sq} \mathrm{km}$ hemmed in all sides by Aravalli hills. About 7 miles from the city is Pushkar lake created by the touch of lord Brahma. The Dargah of khawaja Moinuddin chisti is holiest shrine next to Mecca in the world. Ajmer has hot dry summer and cold bracing winter. The winter extends from November to February and summer extends from March to June followed by rainy season till mid September. The temperature varies from $2 \mathrm{oc}$ in winter and $490 \mathrm{c}$ in summer. The normal annual rainfall is $527.3 \mathrm{~mm}$. The total population of the district is 2180526 persons. Around $5.56 \%$ of total area available for land utilization is covered under forest. Ajmer is abode of certain flora and fauna that are particularly endemic to semi-arid and are specially adapted to survive in the dry waterless region of the state. Out of 19 orders of reptiles 4 survive today. Rhynchocephalia Single living species Tuatara, Sphellodoll pz 111 ctatlts, found only in Newzealand. .Testudines (Turtles, Tortoises, and Terrapins).Of these one species of Tortoise (Star Tortoise), Geochelone elegans is found in Ajmer. .Crocodylia (Gharial and Crocodole)..Squamata (Lizards and Snakes). Reptiles Lizards and Snakes are of immense ecological importance. Reptile diversity is highest in Deserts. But now these are declining at fast rate. 25 species of Reptiles are recorded from Ajmer out of which 16 species of Lizards and 8 species of snakes. Reptiles are specially adapted to survive dry waterless region of the state.
\end{abstract}

Keywords: Faunal diversity, Lizards, Snakes, Aravalis, Ajmer.

Geographical Identification of the Area Rajasthan

\section{Introduction}

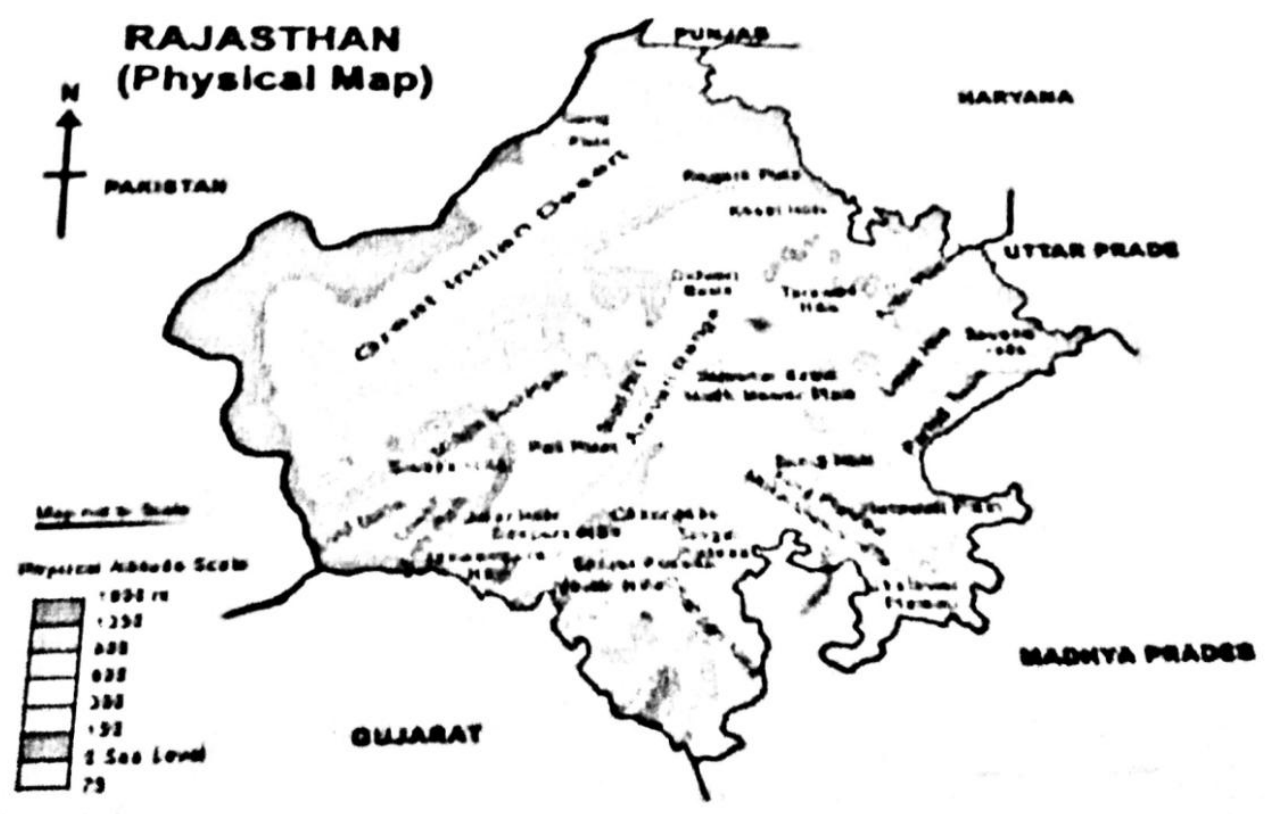

Geographical identification of Ajmer 


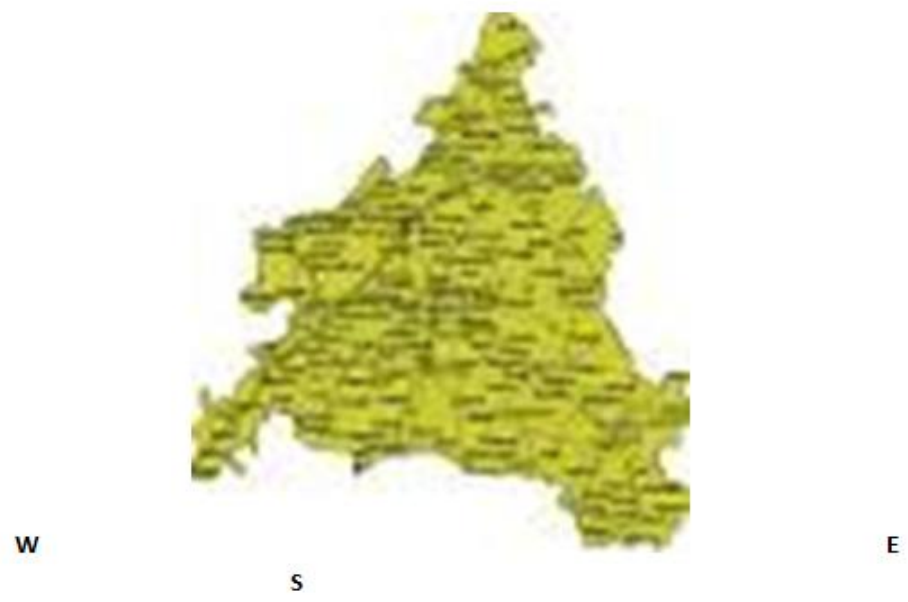

Ajmer is located in the center of Rajasthan (INDIA) between 25038 " and 26058 " north Latitude and 73054 " and 75022 " east longitude covering a geographical area of about 8481sq km hemmed in all sides by Aravalli hills . The district is somewhat triangular in shape. It is centrally located in Rajasthan also known as heart of Rajasthan. About 7 miles from the city is Pushkar lake created by the touch of lord Brahma. The Dargah of khawaja Moinuddin chisti is holiest shrine next to Mecca in the world. Ajmer has hot dry summer and cold bracing winter. The winter extends from November to February and summer extends from March to June followed by rainy season till mid September. The temperature varies from $2 \mathrm{o} \mathrm{c}$ in winter and $490 \mathrm{c}$ in summer. The normal annual rainfall is $527.3 \mathrm{~mm}$. The total population of the district is 2180526 persons. Around $5.56 \%$ of total area available for land utilization is covered under forest. Ajmer is abode of certain flora and fauna that are particularly endemic to semi-arid and are specially adapted to survive in the dry waterless region of the state. The word faunal refers to assemblage of animals of a region or the list of taxonomic entities of animals to be found in an area. And floral refers to plant biodiversity. The year 2010 has been declared as International year of biodiversity The IUCN Red list estimates that $12-52 \%$ species within well studied higher taxa such as vertebrates are threatened with extinction. The total number of species known to currently exist in the world are $1,589,361$. Of which Reptiles are 8,240, Source Faunal diversity in India. India ENVIS centre Zoological Survey of India. 1998.

\section{Materials and methods}

The present studies were carried out during the year 2014. The identification is was mainly based on morphometric observation and high resolution close up photographs using still and video digital camera ( Nikon, ISony H50). . They were identified, photographed and relieved in their habitat. Notpad is essential to note down and sketch the species seen. Surveying Reptiles is done by direct observation the feeding and watering sites attract these animals. Animals were identified and classified using the standard method of taxonomy.

\section{Observation and Results}

There is a strong relationship between presence of certain tree species and animals, with herbs and grasses. Ecological vegetation of the study area fall under the catogary of thorn forest type. Some changes are seen due to cultivation and changes in soil conditions the natural vegetation has a substantial contribution to the productivity of trees like Khejri, khimp, keekar, rohera, neem, prosopis cineraria, which are highly valued and maintained. 14 Species of Lizards, 8 Species of snakes, and 1 species of Tortoise are identified In the area. Table 1.

Table1 List of Reptiles of Ajmer

\begin{tabular}{|l|l|l|l|}
\hline Zoological name & Common name & Abundance & Preffered habitat \\
\hline Stenodactylus orientalis & gecko & o & T \\
\hline Cyrtodactylus scaber & Garden gecko & $\mathrm{F}$ & $\mathrm{T}$ \\
\hline Hemidactylus brooki & Spotted house gecko & $\mathrm{F}$ & $\mathrm{T}$ \\
\hline H. triendrus & Gecko & $\mathrm{F}$ & $\mathrm{T}$ \\
\hline H. leschenaulti & Bark gecko & $\mathrm{F}$ & $\mathrm{T}$ \\
\hline H. flaviviridis & Yellow bellied gecko & $\mathrm{O}$ & $\mathrm{T}$ \\
\hline Calotes versicolor & Garden lizard & $\mathrm{F}$ & $\mathrm{T}$ \\
\hline Agama agilis & Agama & $\mathrm{R}$ & $\mathrm{T}$ \\
\hline Agama minor & Agama & $\mathrm{R}$ & $\mathrm{T}$ \\
\hline Phrynocephalus laung walensis & Frynosoma & $\mathrm{R}$ & $\mathrm{T}$ \\
\hline
\end{tabular}


Faunal diversity of Ajmer Aravalis with special reference to Reptiles

\begin{tabular}{|l|l|l|l|}
\hline Uromastix hardiwicki & Spiny tailed lizard & $\mathrm{O}$ & $\mathrm{T}$ \\
\hline Ophiomorus tridactylus & Sand skink & $\mathrm{O}$ & $\mathrm{T}$ \\
\hline Acanthodactylus cantoris cantoris & Fringed toed lizard & $\mathrm{R}$ & $\mathrm{T}$ \\
\hline Ophisops microlepis & Cobra eyed lizard & $\mathrm{R}$ & $\mathrm{T}$ \\
\hline O. jerdoni & Golden striped lizard & $\mathrm{O}$ & $\mathrm{T}$ \\
\hline Varanus bengalensis & Monitor lizard & $\mathrm{F}$ & $\mathrm{T}$ \\
\hline Ramphotyphlops bramina & Blind snake & $\mathrm{O}$ & $\mathrm{T}$ \\
\hline Leptotyphlops macrorhynchus & Beaked thread snake & $\mathrm{O}$ & $\mathrm{T}$ \\
\hline Eryx johni johni & Sand boa & $\mathrm{O}$ & $\mathrm{T}$ \\
\hline Ptyas mucosus & Dhaman & $\mathrm{O}$ & $\mathrm{T}$ \\
\hline Argyrogena ventromaculatus & Glossy bellied rasev & $\mathrm{O}$ & $\mathrm{T}$ \\
\hline Bungarus cacrulus & Krait & $\mathrm{F}$ & $\mathrm{T}$ \\
\hline Naja naja naja & cobra & $\mathrm{F}$ & $\mathrm{T}$ \\
\hline Echis carinatus & viper & $\mathrm{F}$ & $\mathrm{T}$ \\
\hline Geochelone elegans & Star Tortoise & $\mathrm{F}$ \\
\hline
\end{tabular}

Lizards

1. Stenodactylus orientalis

2. Cyrtodactylus scaber

3. Hemidactylus brooki

4. H. triendrus

5. Bark gecko H. Leschenaultia

6. Yellow bellied house gecko H. Flaviviridis

7. Calotes versicolor

8. Agama agilis

9. Agama minor

10. Uromastix hardiwicki

11. Indian sand skink Ophiomorus tridactylus

12. Indian sand lizard Acanthodactylus cantoris cantoris

13. Cobra eyed lizard Ophisops jerdoni

14. Monitor lizard Varanus bengalensis

\section{Tortoise}

1 Star tortoise Geochelon elegans

Snakes

1. Blind snake Ramhpotyphlops

2. Beaked thread snake Leptotyphlops macrorhynchus

3. ndian sand boa Eryx johni johni

4. Dhaman Ptyas mucosus

5. Indian krait Bungarus Carulcus

6. Cobra Naja naja naja

7. Russels viper Vipera russelli russelli

8. Viper Echis carinatus.

\section{Summary and Conclusion}

The fauna are particularly adapted to semiarid conditions. 24 species of Reptiles are found out of which 16 species of Lizards and 08 species of Snakes.

\section{The faunal diversity observed}

House gecko, Hemidactylus brooki, H. trirendrus, H. Leschenaultia, H. Fleviviridis, Calotes , Cyrtodactylus scaber, Agama agilis, A. minor, Uromastix hardiwicki, Skink Ophiomorus tridactylus, Acanthodactylus cantoris cantoris, Ophisops jerdoni, Varanus bengalensis, Blind snake Ramphotyphlops, Thread snake Leptotyphlops macrorhynchus, Sand boa Eryx johni, Dhaman Ptyas mucosus, Krait Bungarus carulcus, Cobra Naja naja naja, Russel viper Vipera russeli russelli, Viper Echis charinatus. Calotes versicolor, Stenodactylus orientalis. Aravalli Mountains are Marvellous to be viewed, since these are oldest Mountains of the world . But the faunal diversity is rapidly decreasing, due to mining and fast rate of urbanisation. Zinc mining and cutting of mountains to obtain rock for building houses and buildings is the main cause for loss of biodiversity . Fast steps should be taken and hard laws should be introduced to stop the loss of biodiversity.

\section{Suggestions}

- Strict laws should be imposed to stop minning and mountain cutting, since Aravallis are the oldest mountains of the world and habitat of many animals eg Snakes, Lizards. Habitat loss will lead to biodiversity loss. 
- The local people should be educated and made aware of effects and consequences of Biodiversity loss.

- Documentation of biodiversity is an urgent requirement as latest statistics and data on floral and faunal biodiversity has not been compiled and documented.

- Degradation / Fragmentation of habitat extinction of species and destruction of unique habitat need to be monitored.

- A programme " Eco -development " for in situ conservation of biological diversity involving local communities has been initiated in recent years, for sustained conservation of ecosystem by involving the local communities with maintainance of earmarked regions surrounding protected areas.

- Increase allocation of financial resources for conservation of biodiversity.

- To conserve representative ecosystem, a biosphere reserve programme should be implemented. . Aravallis should also be included in Biosphere reserves.

- Major central acts relevant to biodiversity include forest act, and wildlife protection act, 1972, Forest conservation act 1980 and environment protection act 1986.

\section{References}

[1]. https://en.wikipedia.org/wiki/Ajmer.

[2]. Alfred, J. R. B., A. K. Das and A. K. Sanyal.2002.Ecosystems of India.Published by the ENVIS Centre,Zool. Surv. India, Kolkata. 410 pp.

[3]. A Remote Sensing and GIS Approach. Rec. zool. Surv. India, Occ. Paper.189 : 1- 73.Baqri, Q.H., Rathore, N.S., Prakash, I and Kankane, P.L. 2004.Studies on Faunal diversity in the Thar desert of Rajasthan. Final Technical Report submitted to Ministry of Environment and Forests, Govt. of India. 313pp.

[4]. Editor-Director. 2000. Fauna of Gujarat (Part 1). Published by Director,Zool. Surv. India,Kolkata.8:1 -464.Editor

[5]. Director Zoological Survey of India 2004. Fauna of Gujarat (Part 2). Published by Director,Zool. Surv. India,Kolkata.8: 1-427.Editor-Director. 2004. Fauna of Desert National Park, Rajasthan (Proposed Biosphere Reserve).

[6]. Conservation Area Series. Published by Director, Zool. Su rv. India, Kolkata. 19:1-135.Editor-Director.2009.

[7]. Faunal Resources of TalChhapar Wildlife Sanctuary, Rajasthan. Conservation Area Series (Published by Director,zool. Surv. India, Kolkata).38: 1-66.

[8]. Arunachalam, A., and others. 2005. "Anthropogenic Threats and Biodiversity conservation in Adapha Natural Reserve in the Eastern Himalayas." Current Science 87 (4)

[9]. Ashish Dutta, Biodiversity and Ecosystem conservation.(2006).

[10]. Bhatt, K., R. Vyas \& M. Singh(1999). Herpetofauna of Gir protected areas. Zoos print journal 14(5):27-30.

[11]. Das I. (1997). Resolution of Systematic status of Eublepharis macularis fuscus Borner, 1981 Eublepharidae; Sauria; Squamata) Hamadryad 22:13-20.

[12]. Dr. H.S. Mathur, Biogeography (1999).

[13]. Gaston, Kevin J. (May 2000) Global patterns in biodiversity . Nature 405 (6783);220 227 . Myers, Norman . Mittermeier , Russel A ; Mittermeier ,Cristina G; da FFonseca, Gustano A. , B. Kent, Jennifer (24 feb 2000) Biodiversity Hotspot s for conservation Priorities. Nature 403 (6772) ; 853 858.

[14]. Gayen, N.C. (1999) Asynopsis of the reptiles of Gujarat, western India. Hamadryad 24(1):1-22

[15]. Khan, M.S. (2004) Annotated checklist of amphibians and reptiles of Pakistan. Asiatic Herpetological Research 10: 191-121.

[16]. Khan ,M.S.(2006) Amphibian and Reptiles of Pakistan. Krieger Publishing Company, Malabar, Florida, 311pp.

[17]. L.R. Bhalla, Geography of Rajasthan (2007).

[18]. Minton, S.A. (1966). A contributions to the herpetology of West Pakistan, Bulletin of American Museum of Natural History 134: 27-184.

[19]. Mirza, Z. \& Upadhye (2010). On the distribution and natural history of endemic Eublepharid Gecko Eublepharis fuscus Borner, 1981 in India. Sauria, Berlin 32(3):15-23

[20]. Murray, J.A. (1884). The vertebrate zoology of Sind: A Systematic Account, with Discription Of all the known Mammals, Birds, and Reptiles inhabiting the Province: Observationon the habit,and a table of their Geographical Distribution in Persia Beloochstan, and Afghanistan: Punjab, Northwest Province, and Peninsula of India generally. Education Society 's Press, Byculla, Bombay, and Richardson and Co., London, 424pp.

[21]. M.M. Bhandari, Fauna and flora of Thar desert. during the 20th centuary. J16. Pant C.B., Hingane L.S., (1988) Climatic changes in and around the Rajasthan deserts .climatol 8;391-401.

[22]. Prakash I (2001) survival strategies of desert vertebrates, In Prakash (ed) Ecology of desert environments Scientific publishers, Jodhpur, India, pp 459471

[23]. B. Singh, Biogeography and Biodiversity.

[24]. Rao as, Miyazaki T. (1997) Influenze of climatic changes on the desertification in the Osian (Jodhpur) region of Indian Arid zone. J. Arid Land Studies $7(1) ; 1-11$.

[25]. Rao AS. (2005) Impact of introduction of IGNP canal irrigation on micro secular changes on climate of ther desert region In ; Tyagi BK Baqri Q H (eds) changing faunal ecology in the thar desert vol 3 Scientific publisher, Jodhpur. Pp37-44.

[26]. Rao A.S. (2009) Climate and microclimate changes influenzing the fauna of Hot Indian Arid zone. In ;Sivaperuman C,Baqri Q H , Ramaswamy G, Naseema M (eds) Faunal ecology and conservation the great Indian desert. Springer, Heidelberg, pp 13-24.

[27]. Saxena, M.M. 1997. Hydrozoological diversity of the Aravalli range with special reference to Pushkar valley : Present status and future scope of research. Abst. Conf. Env. Eco - dev. Pushkar Valley of Rajasthan Ajmer. P 91.

[28]. Sharma, R.C. (2000). Reptilia,243-297. In: State Fauna series 8: Fauna of Gujrat ,PART -I. Zoological Survey of India.

[29]. M.A.(1935).The Fauna of British India, including Ceylon and Burma.Reptilia and Amphibia. Vol II: Sauria.Taylor and Francis Ltd.London,440pp.

[30]. Srivastava, Deepti \& Saxena, M. M. 2007. A Cursory survey of the faunal diversity of some village pond ecosystems in the Indian deserts. J. Cell \& Tissue Res., 17 (3) ; 53.

[31]. . . Shrishti Jigyasa Parivar. 2008. "Conserving India's Biodiversity ; Let people speak In S. Singh A. R. K. Sastry, R. Mehta,V. Uppal, eds, Setting biodiversity conservation priorities for India.

[32]. Vidal, N.\&S.B. Hedges (2004). Molecular evidence for a terrestrial origin of snakes. Proceedings of Royal Society of London, B.Supplement 271,S226-S229.

[33]. Vyas, R. (1998) The reptiles of gujrat state.Uploaded distribution. Tiger paper 25(1):8-14.

[34]. Vyas, R. (2000) Herpatofauna of Hingolgadh nature education sanctuary, Gujrat zoos print print journal 15(6);285-286. 36. Vyas R.(2002). Preliminary survey of Herpatofauna of Narayan Sarovar Sanctuary, Gujrat. Zoos Print Journal 17 (6): 812-814

[35]. Vyas, R. (2006) Reptilian diversity of Jambugheda wildlife Sanctuary, Gujarat. Tyer paper 33 (1) 20-23.

[36]. Vyas, R. (2007) Present conservation scenario of reptile fauna in Gujarat state, India, The Indian Forester 133(10):1381-1394.

[37]. Walter, G. Wilford (2001) Invertebrates ; Their effects on the properties and processs of desert ecosystems . In Prakash I (ed) Ecology of desert environments.

[38]. Whitaker, R. \& A. Captain (2004); Snakes of India: Field guide Draco Books, Chennai, IndiaXIV+481 PP. 41 . Winstanley D. (1973) Rainfall patterns and general atmospheric circulation. Nature 245;190-194 